\title{
Prevalence and associated factors of acute diarrhea among under five children living in Hargeisa IDPs, Somaliland
}

Ahmed Ismail Mohamed ( $\nabla$ ahmed.mohamed@uoh-edu.net )

University of Hargeisa

Mohamed Mussa Abdilahi

University of Hargeisa

\section{Research Article}

Keywords: childhood diarrhea, associated factors, community based cross-sectional study, Hargeisa,

Somaliland

Posted Date: April 13th, 2021

DOl: https://doi.org/10.21203/rs.3.rs-355384/v1

License: (a) (i) This work is licensed under a Creative Commons Attribution 4.0 International License. Read Full License 


\section{Abstract}

Background: In developing countries, diarrhea is the major cause for child death when children are less than five years' old. Dehydration, malnutrition, delayed physical development and early childhood mortality are the major consequences of diarrheal diseases. In Somaliland, diarrheal diseases have been endemic and a major problem since 1994, with epidemics occurring annually.

Objective: The aim of this study was to assess prevalence and risk factors of acute diarrhea among under five children living in Hargeisa IDPS, Somaliland

Methods: A community based cross sectional study was conducted among mothers of under five children from August to September, 2020, in Hargeisa IDPs. 383 mothers were selected by using single population proportional formula. Data was entered, cleaned and analyzed using SPSS version 22. To explore association between variables, bivariate logistic regression was done for each independent variable with the dependent variable and those variables with a p-value of $<0.05$ were adjusted into multivariate logistic regression. Finally, those variables having a $P$ value $<0.05$ were recognized as determinants of acute diarrheal disease.

Results: The prevalence of diarrhea among under five children ling in Hargeisa IDPs was $51 \%$. The children whose age older than one year [AOR $=3.586,95 \% \mathrm{Cl}, 1.054,12.196]$, didn't breastfed exclusively [AOR=4.006, 95\% Cl, 3.274, 4.596], didn't met colostrum milk [AOR=36.41, 95\% Cl, 24.312, 40.489], drinks water stored in Jerry-cans [AOR $=4.90195 \% \mathrm{Cl}, 1.306,8.387]$ and poorly practices hand washing [AOR = $5.739,95 \% \mathrm{Cl}, 1.382,7.822]$ were more likely to develop diarrhea than their respective contraparts.

Conclusion: From this study we concluded that the prevalence of was very high (51\%). Lack of awareness of exclusive breastfeeding and colostrum feeding, storing drinking water in unprotected container and poor hand washing practice were identified to be significance predictors for childhood diarrhea $(P<0.05)$.

\section{Background}

According to the WHO, diarrhea is defined as "the passage of three or more loose or liquid stools per day" (1). It's usually a symptom of an infection in the intestinal tract, which have multiple etiologic agents including bacteria, viruses and parasites (2-4). Diarrheal disease is the second leading cause of death in children under five years old. Globally, it is estimated that there are 2.5 billion cases and 1.5 million deaths annually in children under five years $(5,6)$. In developing countries, diarrhea is the major cause for child death when children are less than five years old (6). The morbidity and mortality of diarrhea is attributed by poor socio-economic status, lack of access to safe water, lack of hand washing, poor housing conditions, unsanitary disposal of human waste, improper feeding practices, and lack of access to adequate and affordable health care (7).

Dehydration, malnutrition, delayed physical development and early childhood mortality are the major consenuences of diarrheal diseases (8)

Loading [MathJax]/jax/output/CommonHTML/jax.js

Page 2/18 
In Somaliland, diarrheal diseases have been endemic and a major problem since 1994, with epidemics occurring annually. Very poor sanitation conditions and the human consumption of unsafe water are the main causes of this health situation. IDP camps which have even worse living conditions provide foci for endemic cholera outbreaks (9).

The two studies conducted in Somalia and Somaliland revealed that the prevalence rates of acute diarrhea were $11 \%$ and $47 \%$ respectively. Based on findings of this studies, lack of mother's knowledge towards hand washing at four critical times, drinking unsafe water and failure of exclusive breastfeeding increases the odds of acute diarrheal diseases $(10,11)$.

According the neighbor countries, the prevalence of acute diarrhea in under five-children ranged between $14.5 \%$ and $36.5 \%(12-15)$ in Ethiopia whereas prevalence rates ranging between $10.6 \%$ and $19.6 \%$ reported in Kenya (16) which are lower rates compared to Ethiopia.

This study aimed to assess (1); prevalence of acute diarrhea among under five children (2); to determine socio-demographic and economic of mother and child (3); explore child characteristics; and (4) to determine environmental and hygienic characteristics related to acute diarrhea

\section{Material And Methods \\ 2.1 Study sittings}

A community based cross sectional study was conducted among mothers of under five children from August to September, 2020, in Hargeisa IDPs. Hargeisa is the capital city of Somaliland and locates in the northern part of Somalia. Hargeisa is on latitude $9^{\circ} .5624^{\prime \prime}$ and longitude, $44^{\circ} .177^{\prime \prime}$ and 1,334 meters ( 4,377 feet) of above the sea level with a population of approximately 1.5 million individuals. It has one referral public hospital, eight private hospitals, twenty-five private clinics and ten public MCHs. In the city there are 16 IDP settlements consist of 11,549 households living in 71,606 individuals. 46,544 (65\%) and $17,902(24 \%)$ of them are women and under five children respectively.

\subsection{Sample size determination}

The sample size was determined by using single population proportional formula $\mid \operatorname{varvec} n=\frac{|\operatorname{varvec} z 2| \operatorname{varvec} *|\operatorname{varvec} p| \operatorname{varvec} *(1-\mid \operatorname{varvec} p)}{\mid \operatorname{varvec} d 2}$ with the following assumptions

$\mathrm{n}=$ sample size

$Z=$ confidence interval at $95 \%$ which is 1.96

$\mathrm{P}=$ expected proportion of children who have diarrhea is taken to be $47 \%=0.47$ as reported in study conducted in Sanag region (11). 
After substitution the formula, the final sample size was $\mathbf{3 8 3}$ mothers/caregivers.

\subsection{Sampling procedure}

First, four IDPs (Stadium, Ayaxa 1, Digale and Ayaxa 2) was selected from total 16 IDPs in the city by using simple random sampling method followed by allocation of each IDP to probability sample proportional to its size. Household numbers having under-five children were taken from health extension workers registration books in the MCHs. Systemic random sampling was used to select households. The youngest child was selected for a household having two or more under 5 years of children. (Fig. 1)

\subsection{Study variables}

The dependent (outcome) variable of this study was the status of acute diarrheal disease in under five children as reported by the mother/caregiver of the child in two-week period prior to the survey.

The independent variables were socio-demographic characteristics of mother (maternal age, occupation, educational level, household income and household size); child characteristics (child's age, child's sex, vaccination status, EBF practice and colostrum feeding); environmental and hygienic factors (water storage container, hand washing practice at critical times, household floor type and frequency of latrine utilization).

\subsection{Data collection procedure}

Structured questionnaire was first prepared in English and then translated to Somali language. Retranslation was also being made to see the consistency of both questionnaires. After this, the questionnaire was used in interviewing the study participants through face to face interview method. Data collection was facilitated by health professionals using structured and pretested questionnaire.

\subsection{Data quality control}

Continuous guidance and supervision from principle investigator was done to keep data quality. The data collectors were trained for one day on the study instrument, consent form, how to interview and data collection procedures. Data was checked and rechecked for reliability and the questionnaire was pretested by $10 \%$ of sample size.

\subsection{Data processing and analysis}

The completeness of questionnaire was checked visually and coded with a whiteboard marker. Then was entered, cleaned and analyzed using SPSS version 22. Frequency tables and graphs were used to summarize the socio-demographic characteristics of the study participants and magnitude of diarrhea. To explore association between status and risk factors, bivariate logistic regression was done for each independent variable with the dependent variable and those variables with a $p$-value of $<0.05$ were adjusted into multivariate logistic regression. Finally, those variables having a P value $<0.05$ were recognized as determinants of acute diarrheal disease. 


\section{Results}

\subsection{Socio-demographic characteristics of mothers and her child}

Total 348 mother-child pairs participated in this study making a response rate of $90.8 \%$. Majority of mothers 158 (45.4\%) were aged between 26 and 35 years' old. One-hundred fifty (43.1\%) of them were illiterate whereas only 30 (8.6\%) were diploma level and above. According to occupation, more than twothird $233(67 \%)$ of mothers were housewives. More than half $187(53.7 \%)$ of households were lived 5-8 individuals and only $58(16.7 \%)$ of them were lived more than eight individual. Furthermore, fifty-five percent of households were lived 2-4 under five children and half of them were used monthly income ranged between $50 \$$ and $100 \%$ (Table 1 ). 
Table 1

Socio-demographic characteristics of mothers and her children living in Hargeisa IDPs Somaliland 2020.

\begin{tabular}{|c|c|c|c|}
\hline Variables & Categories & $\mathbf{N}$ & $\%$ \\
\hline \multirow[t]{4}{*}{ Maternal age (348) } & $15-25$ & 63 & 18.1 \\
\hline & $26-35$ & 158 & 45.4 \\
\hline & $36-45$ & 86 & 24.7 \\
\hline & $>45$ & 41 & 11.8 \\
\hline \multirow[t]{4}{*}{ Maternal education (348) } & Illiterate & 150 & 43.1 \\
\hline & Primary level & 133 & 38.2 \\
\hline & Secondary level & 35 & 10.1 \\
\hline & Diploma level and above & 30 & 8.6 \\
\hline \multirow[t]{4}{*}{ Maternal occupation (348) } & Housewife & 233 & 67.0 \\
\hline & Merchant & 72 & 20.7 \\
\hline & Government employer & 12 & 3.4 \\
\hline & Salaried woman & 31 & 8.9 \\
\hline \multirow[t]{3}{*}{ Household size } & $2-4$ & 103 & 29.6 \\
\hline & $5-8$ & 187 & 53.7 \\
\hline & $>8$ & 58 & 16.7 \\
\hline \multirow[t]{3}{*}{ Number of under five children } & Only one & 152 & 43.7 \\
\hline & $2-4$ & 190 & 54.6 \\
\hline & $>4$ & 6 & 1.7 \\
\hline \multirow[t]{4}{*}{ Household monthly income (USD) } & $50 \$-100 \$$ & 180 & 51.7 \\
\hline & $101 \$-150 \$$ & 73 & 21.0 \\
\hline & $151 \$-200 \$$ & 39 & 11.2 \\
\hline & $>200 \$$ & 56 & 16.1 \\
\hline
\end{tabular}

\subsection{Demographic and health characteristics of indexed child}

More than half $(52.6 \%)$ of children were males. $23.3 \%, 37.9 \%$ and $38.8 \%$ of them were aged less than one year, 1-2 year and 3-5 year respectively. Two-hundred and seven (59.5\%) of children received measles vaccination. About one-third (30.1\%) didn't fed breast milk exclusively, whereas eight percent of them met 
colostrum (Table 2). 178 (50.1\%) children had diarrhea in two weeks' prior the data collection. Majority of them (82\%) had watery type of diarrhea (Fig. 2).

Table 2

Demographic and health characteristics of indexed child living in Hargeisa IDPs Somaliland 2020.

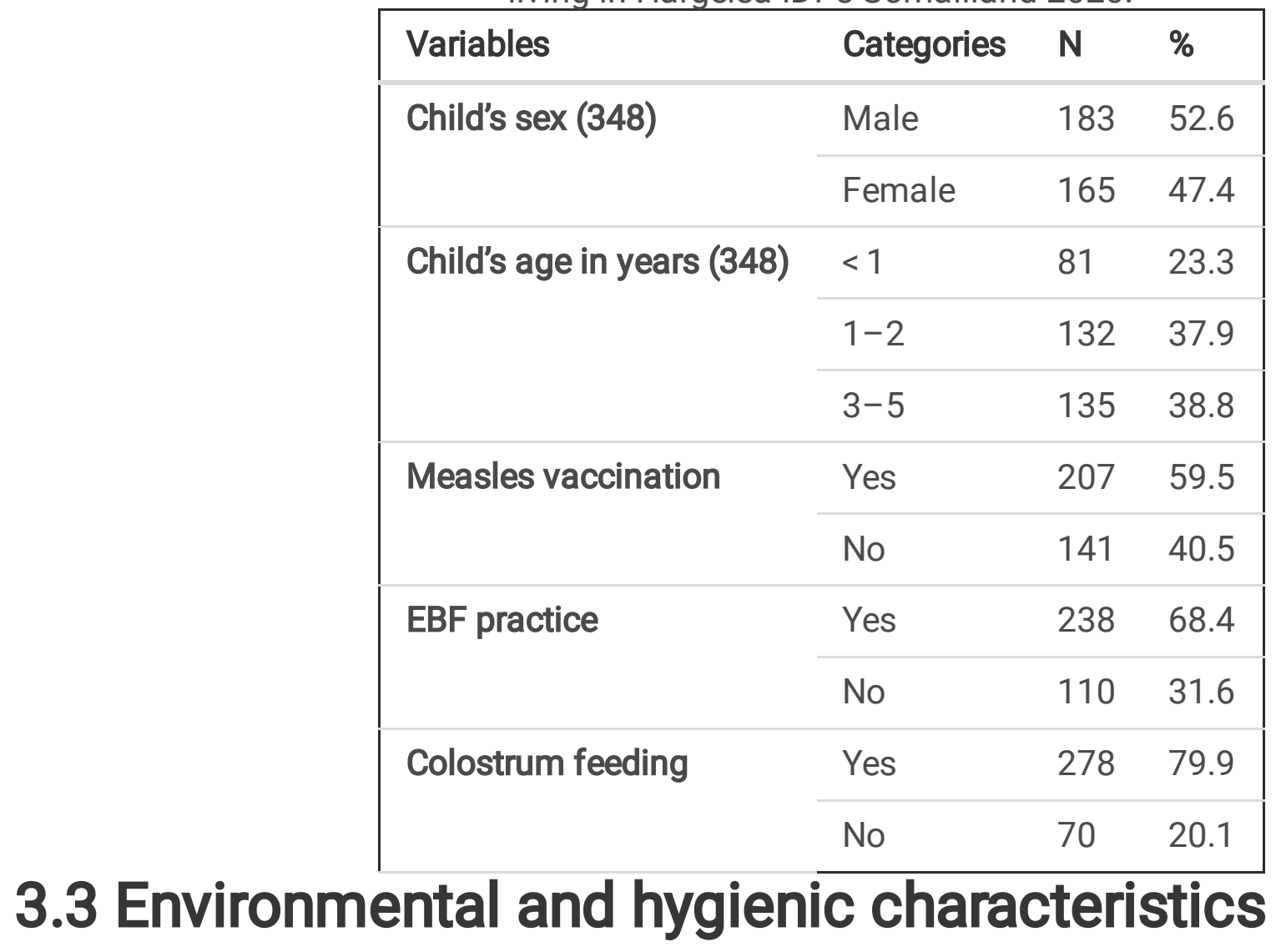

Majority 274 (78.7\%) of households were used metal tank for water storage container. One hundred $(28.7 \%)$ of children were rarely practiced hand washing at critical times where as $40.2 \%$ and $31 \%$ of them were sometimes and often practiced handwashing respectively. Considering with the livestock ownership, fourth-three percent of households had at least one kind of livestock mainly goats. Only fifty-eight $(16.7 \%)$ of households had mud floor. All households had toilets however less than half $(46.8 \%)$ of children were rarely used that latrines (Table 3 ). 
Table 3

Environmental and hygienic characteristics of

households in Hargeisa IDPs Somaliland 2020

\begin{tabular}{|c|c|c|c|}
\hline & & & \\
\hline Variables & Categories & $\mathbf{N}$ & $\%$ \\
\hline \multirow[t]{2}{*}{ Water storage container } & Jerry can & 74 & 21.3 \\
\hline & Tank & 274 & 78.7 \\
\hline \multirow[t]{3}{*}{ Hand washing practice } & Rarely & 100 & 28.7 \\
\hline & Sometimes & 140 & 40.2 \\
\hline & Often & 108 & 31.0 \\
\hline \multirow[t]{2}{*}{ Livestock ownership } & Yes & 150 & 43.1 \\
\hline & No & 198 & 56.9 \\
\hline \multirow[t]{3}{*}{ Household floor } & Mud & 58 & 16.7 \\
\hline & Cement & 217 & 62.4 \\
\hline & Tiles & 73 & 21.0 \\
\hline \multirow[t]{3}{*}{ Latrine utilization } & Rarely & 163 & 51.7 \\
\hline & Sometimes & 78 & 24.8 \\
\hline & Often & 74 & 23.5 \\
\hline \multirow[t]{2}{*}{ Waste management } & Poor & 253 & 72.7 \\
\hline & Good & 95 & 27.3 \\
\hline
\end{tabular}

\subsection{Factors associated with diarrhea}

In bivariate regression analyses, significance variables ( $p$-value $\leq 0.05$ ) that may contribute the occurrence of childhood diarrhea were noted by maternal education, household monthly income, child's age, measles vaccination exclusive breastfeeding practice, colostrum feeding, water storage container, hand washing practice, livestock ownership, floor materials of household, frequency of latrine utilization and waste management (Table 4). 
Table 4

Binary logistic regression analysis of factors associated with diarrheal diseases among under five children living in Hargeisa IDPs Somaliland.

\begin{tabular}{|c|c|c|c|c|c|}
\hline \multirow[t]{2}{*}{ Variable } & \multirow[t]{2}{*}{ Categories } & \multicolumn{2}{|c|}{$\begin{array}{l}\text { Diarrhea } \\
\text { occurrence }\end{array}$} & \multirow[t]{2}{*}{ COR $(95 \% \mathrm{Cl})$} & \multirow[t]{2}{*}{$\begin{array}{l}\mathrm{P}- \\
\text { Value }\end{array}$} \\
\hline & & No & Yes & & \\
\hline \multirow[t]{3}{*}{ Maternal occupation } & Housewife & 138 & 95 & 1 & \\
\hline & Merchant & 12 & 60 & $7.263(3.707,14.231)$ & $0.000 *$ \\
\hline & $\begin{array}{l}\text { Salaried } \\
\text { woman }\end{array}$ & 11 & 20 & $2.641(1.210,5.766)$ & $0.015^{\star}$ \\
\hline \multirow[t]{4}{*}{ Household monthly income } & $50 \$-100 \$$ & 94 & 86 & $1.931(1.026,3.636)$ & $0.041 *$ \\
\hline & $101 \$-150 \$$ & 29 & 44 & $3.203(1.542,6.653)$ & $0.002 *$ \\
\hline & $151 \$-200 \$$ & 9 & 30 & $7.037(2.770,17.878)$ & $0.000 *$ \\
\hline & $>200 \$$ & 38 & 18 & 1 & \\
\hline \multirow[t]{3}{*}{ Child's age (years) } & $<1$ & 51 & 30 & 1 & \\
\hline & $1-2$ & 62 & 70 & $1.919(1.090,3.380)$ & $0.024 *$ \\
\hline & $3-5$ & 57 & 78 & $2.326(1.321,4.096)$ & $0.003^{*}$ \\
\hline \multirow[t]{2}{*}{ Measles vaccination status } & Yes & 120 & 87 & 1 & \\
\hline & No & 50 & 91 & $2.510(1.614,3.905)$ & $0.000 *$ \\
\hline \multirow{2}{*}{$\begin{array}{l}\text { Exclusive breastfeeding } \\
\text { practice }\end{array}$} & Yes & 137 & 101 & 1 & \\
\hline & No & 33 & 77 & $3.165(1.954,5.125)$ & $0.000 *$ \\
\hline \multirow[t]{2}{*}{ Colostrum feeding } & Yes & 167 & 111 & 1 & \\
\hline & No & 13 & 67 & $\begin{array}{l}33.601(24.312 \\
40.489)\end{array}$ & $0.000 *$ \\
\hline \multirow[t]{2}{*}{ Water storage container } & Jerry can & 18 & 66 & $\begin{array}{l}11.933(5.513 \\
25.831)\end{array}$ & $0.000 *$ \\
\hline & Tank & 162 & 112 & 1 & \\
\hline \multirow{3}{*}{$\begin{array}{l}\text { Hand washing practice of } \\
\text { child }\end{array}$} & Rarely & 36 & 64 & $3.869(2.175,6.882)$ & $0.000 *$ \\
\hline & Sometimes & 60 & 80 & $2.9021 .715,4.912)$ & $0.000 *$ \\
\hline & Often & 74 & 34 & 1 & \\
\hline \multirow[t]{2}{*}{ Livestock ownership } & Yes & 52 & 98 & $2.780(1.790,4.316)$ & $0.000 *$ \\
\hline & No & 118 & 80 & 1 & \\
\hline
\end{tabular}




\begin{tabular}{|c|c|c|c|c|c|}
\hline \multirow[t]{2}{*}{ Variable } & \multirow[t]{2}{*}{ Categories } & \multicolumn{2}{|c|}{$\begin{array}{l}\text { Diarrihea } \\
\text { occurrence }\end{array}$} & \multirow[t]{2}{*}{ COR (95\% Cl) } & \multirow[t]{2}{*}{$\begin{array}{l}\text { P- } \\
\text { Value }\end{array}$} \\
\hline & & No & Yes & & \\
\hline \multirow{3}{*}{$\begin{array}{l}\text { Floor materials of } \\
\text { household }\end{array}$} & Mud & 21 & 37 & $3.597(1.743,7.425)$ & $0.001 *$ \\
\hline & Cement & 100 & 117 & $2.389(1.369,4.167)$ & $0.002^{*}$ \\
\hline & Tile & 49 & 24 & 1 & \\
\hline \multirow{3}{*}{$\begin{array}{l}\text { Frequency of latrine } \\
\text { utilization }\end{array}$} & Rarely & 54 & 109 & $5.094(2.792,9.296)$ & $0.000 *$ \\
\hline & Sometimes & 48 & 30 & $1.577(0.798,3.116)$ & 0.189 \\
\hline & Often & 53 & 21 & 1 & \\
\hline \multirow[t]{2}{*}{ Waste management } & Poor & 108 & 145 & $2.522(1.545,4.119)$ & $0.000 *$ \\
\hline & Good & 62 & 33 & 1 & \\
\hline
\end{tabular}

The variables which were significant ( $p$-value $\leq 0.05$ ) during bivariate analysis were further considered in multivariate regression analysis in order to control potential confounders (Table 5).

Accordingly, being a child age is older than one year; being a child who had poor hand washing practice; being from mothers not breastfed their children exclusively; being a child didn't meet colostrum milk and storing drinking water by jerry cans were found to be independent predictors of diarrheal disease in children.

Children whose age ranged between one and two years were 3.586 times more likely to have diarrhea than those aged less than one year [AOR $=3.586,95 \% \mathrm{Cl}, 2.054,5.196]$. Exclusive breastfeeding practice was also significantly associated with childhood diarrhea. The children who didn't fed breast milk exclusively were 4.006 times more likely to have diarrhea than those who fed [AOR $=4.006,95 \%$ $\mathrm{Cl}, 3.274,4.596]$.

The children who didn't meet colostrum milk were 36.41 times higher risk to develop diarrhea compared to those who fed early colostrum milk [AOR $=36.41,95 \% \mathrm{Cl}, 24.312,40.489]$. Moreover, the children living in households using Jerry-cans for water storage were 4.9 times more risk to have diarrhea than those used raised tanks [AOR $=4.90195 \% \mathrm{Cl}, 1.306,8.387]$.

The risk of developing diarrhea was higher among children who rarely practices hand washing [AOR = $5.739,95 \% \mathrm{Cl}, 1.382,7.822]$ and those whose sometimes practices [AOR $=3.201,95 \% \mathrm{Cl}, 1.002,5.354$ ] when compared with children who had good hand washing practice. 
Table 5

Multivariate logistic regression analyses of factors associated with diarrheal diseases among under five children in Hargeisa IDPs Somaliland, 2020

\begin{tabular}{|c|c|c|c|c|c|}
\hline \multirow[t]{2}{*}{ Variable } & \multirow[t]{2}{*}{ Categories } & \multicolumn{2}{|c|}{$\begin{array}{l}\text { Diarrhea } \\
\text { occurrence }\end{array}$} & \multirow[t]{2}{*}{ AOR (95\% Cl) } & \multirow[t]{2}{*}{$\begin{array}{l}\mathrm{P} \text { - } \\
\text { Value }\end{array}$} \\
\hline & & No & Yes & & \\
\hline \multirow[t]{3}{*}{ Child's age (years) } & $<1$ & 51 & 30 & 1 & \\
\hline & $1-2$ & 62 & 70 & $\begin{array}{l}3.586(2.054 \\
5.196)\end{array}$ & $0.041^{*}$ \\
\hline & $3-5$ & 57 & 78 & $\begin{array}{l}1.143(0.259 \\
5.049)\end{array}$ & 0.860 \\
\hline \multirow{2}{*}{$\begin{array}{l}\text { Exclusive breastfeeding } \\
\text { practice }\end{array}$} & Yes & 137 & 101 & 1 & \\
\hline & No & 33 & 77 & $\begin{array}{l}4.006(3.274 \\
4.596)\end{array}$ & $0.018^{*}$ \\
\hline \multirow[t]{2}{*}{ Colostrum feeding } & Yes & 167 & 111 & 1 & \\
\hline & No & 13 & 67 & $36.41(25.76,47.9)$ & $0.000 *$ \\
\hline \multirow[t]{2}{*}{ Water storage container } & Jerry can & 18 & 66 & $\begin{array}{l}\text { 4.901 (1.306, } \\
8.387)\end{array}$ & $0.018 *$ \\
\hline & Tank & 162 & 112 & 1 & \\
\hline \multirow[t]{3}{*}{ Hand washing practice of child } & Rarely & 36 & 64 & $\begin{array}{l}5.739(1.382 \\
7.822)\end{array}$ & $0.016^{\star}$ \\
\hline & Sometimes & 60 & 80 & $\begin{array}{l}3.201(1.002 \\
5.354)\end{array}$ & $0.042^{\star}$ \\
\hline & Often & 74 & 34 & 1 & \\
\hline
\end{tabular}

* Significant association as $\mathrm{p}$-value $<0.05, \mathrm{AOR}=$ adjusted odds ratio, $\mathrm{Cl}=$ confidence interval

\section{Discussion}

The two weeks' prevalence of diarrhea among under five children in Hargeisa IDPs was $51 \%$. The findings of this study was extremely very high compared to SLHDS 2020 report which was only $4 \%$. However closely related results of $47 \%$ were reported from Ceel-afwayn distric in Sanag region (11). Current studies conducted in Somalia, 11\% (10), Ethiopia, 26\% (17), Kenya, 19.6\% (16) and Tanzania, 12.1\% (18) shows lower results compared to the findings of this study. This variation may be attributed to; the current study setting consider only urban dwellers; differences in socio-demographic characteristics, environmental factors (climate and geographical differences) and behavioral factors (availability of water, presence and usage of latrine, availability of hand washing facilities and ways of waste disposal in the study area compared to other studies. 
Children whose age ranged between one and two years were 3.586 times more likely to have diarrhea than those aged less than one year $[\mathrm{AOR}=3.586,95 \% \mathrm{Cl}, 1.054,12.196]$. The finding is supported with that of other similar studies conducted in other areas (19-23). This may be justified so because children aged more than one-year start crawling or walking which increases their exposure to infectious agents. Moreover, such children start complementary feeding, and this may increase their exposure to different types of infections through contaminated food and water.

Exclusive breast feeding was found to be a significant predictor of diarrheal morbidity in children as breastfeeding is an effective means of protecting children from diarrheal disease $(24,25)$. For those children who didn't breastfed exclusively from their mothers were 4 times more likely to develop diarrhea than those who breastfed exclusively [AOR $=4.00695 \% \mathrm{Cl}, 3.274,4.596]$. Similar finding were revealed from other studies (26-29). This is because of the presence of secretory immunoglobulin A (slgA) in the milk. The IgA protects the mucus membranes of the gastro-intestinal tract from the adherence of microbes that could cause diarrhea in children. There are other protective molecules in the breast milk such us $\lg G$, IgM, IgD, lactoferin, lacto-peroxidases and different kinds of leukocytes.

The colostrum is defined as a sticky white or yellow fluid secreted by the breasts during the second half of pregnancy and for a few days after birth, before breast milk comes in. Mothers colostrum provides effective passive immunity to the newborn against a wide range of enteric pathogens in the form of antibodies. They are central to the immunological link that occurs when the mother transfers passive immunity to the offspring (30). Therefore, this study revealed that the children who didn't met colostrum were 36.4 times more risk to have diarrhea compared to those who fed colostrum milk [AOR $=36.4195 \%$ $\mathrm{Cl}, 25.76,47.9]$. In most published literatures, colostrum milk is reported to be preventive measure for morbidity of various gastro-intestinal infections, but not in treatment of an established infection (30-34).

Unprotected water storage container is among the potential sources for diarrheal diseases transmission. The chance of contamination of water sources depends on whether the container is protected or not. Households using Jerry-cans for water storage were 4.9 times more likely to have a child with diarrhea than those using raised tanks [AOR $=4.90195 \% \mathrm{Cl}, 1.306,8.387]$. This current study is in agreement with the study conducted in Ethiopia (35), but it contradicts with other study in that country (36). This might be due to the fact that there might be mixed use of water from both protected and unprotected sources, contamination during transport and storage or lack of homogeneity in source of water. Furthermore, frequency of hand washing practices in children was found to be independent predictor for morbidity of childhood diarrhea. Children who rarely and sometimes practices hand washing were 5.7 times and 3.2 times respectively increases the occurrence of diarrhea compared to those often practices [A0R $=5.739$, $95 \% \mathrm{Cl}, 1.382,7.822$ and $\mathrm{AOR}=3.20195 \% \mathrm{Cl}, 1.002,5.354]$. Since hand washing practice ensures the elimination of microbes from the nails in hands, its missing increases the exposure of microbes through the food and drink.

From this study we concluded that the prevalence of was very high (51\%). Lack of exclusive breastfeedina colostrum discharae. storina drinking water in unprotected container and poor hand Loading [MathJax]/jax/output/CommonHTML/jax.js

Page $12 / 18$ 
washing practice were identified to be significance predictors for childhood diarrhea $(P<0.05)$. Its highly recommended to pay special attention in EBF promotion: health care providers and decision makers should comprehensively address issues to improve EBF practices in the community. Moreover, implementation of health education programs towards importance of colostrum milk and hand washing practice could reduce the morbidity of childhood diarrhea.

\section{Limitations}

Not using enough literatures from the surrounding towns on the study area in specific due to the unavailability of published journals on the topic of interest could be mentioned as a limitation. In addition to that, this study was cross-sectional study design, which made it difficult to establish causal effect relationship.

\section{Declarations}

\section{Ethical Considerations}

The study protocol was reviewed and approved by Ethical review committee of University of Hargeisa. Before data collection, written or oral agreement was obtained from the respondents such as parents and caregivers. informed consent was obtained from all a parent and/or legal guardian for participants under 18 and illiterates. Acceptance Permission of the study was obtained from every relevant authority in the Hargeisa city. Data collection was conducted confidentially. All methods were carried out in accordance with relevant institutional guidelines and regulations.

\section{Competing interests}

The authors declare that there are no competing interests.

\section{Consent for publication}

Not applicable

\section{Authors' contribution}

A.I.M wrote first draft of manuscripts from idea generation, proposal development, analysis and interpretation of data. M.M.A participated in reviewing, data analysis. Both authors read and approved the final draft of manuscript. 


\section{Acknowledgment}

The author's gratitude goes to The University of Hargeisa, Research and community service core process for ethical support. We would like to thank the study subjects for their participation and acceptance to be involved in the study. We also would like to extend our heartfelt gratitude to the health care providers who helped with data collection.

\section{Funding}

No external funding source for this study.

\section{References}

1. Diarrheal Diseases. Wold Health Organisation. 2017.

2. BARTRAM J. UNSAFE WATER, SANITATION. Comparative quantification of health risks. 2004:1321.

3. Podewils LJ, Mintz ED, Nataro JP, Parashar UD, editors. Acute, infectious diarrhea among children in developing countries. Seminars in pediatric infectious diseases; 2004: Elsevier.

4. Sherchand JB, Yokoo M, Sherchand O, Pant AR, Nakogomi O. Burden of enteropathogens associated diarrheal diseases in children hospital, Nepal. Scientific World. 2009;7(7):71-5.

5. Mumtaz Y, Zafar M, Mumtaz Z. Knowledge attitude and practices of mothers about diarrhea in children under 5 years. J Dow Uni Health Sci. 2014;8(1):3-6.

6. Major causes of children mortality in developing countries Report. 2000.

7. Keusch GT. OF and Alok B.(2001). Disease Control Priorities in Developing Countries.371-88.

8. Dosha TD, editor Practice of mothers/caregivers on home management of diarrhea in under-five children in Mareka district, Southern Ethiopia-A community based cross sectional study. 30th EPHA Annual Conference; 2019.

9. Organization WH. Horn of Africa: emergency-affected countries 2007: communicable disease epidemiological profile. World Health Organization, 2007.

10. Kalid M, Omar E, Ibrahim A, Said S, Farah DA. Factors related to the occurrence of diarrheal disease in under-five children of IDP's in Bosaso, Puntland-Somalia. World J Med Sci. 2016;13(1):54-9.

11. HILLOW HS. CAREGIVERS KNOWLEDGE AND PRACTICES IN MANAGEMENT OF DIARRHOEA AMONG CHILDREN AGED 6-59 MONTHS IN CEELAFWEYN DISTRICT, SANAG REGION, SOMALILAND: KENYATTA UNIVERSITY; 2018.

12. Dagnew AB, Tewabe T, Miskir Y, Eshetu T, Kefelegn W, Zerihun $K$, et al. Prevalence of diarrhea and associated factors among under-five children in Bahir Dar city, Northwest Ethiopia, 2016: a crosssectional study. BMC infectious diseases. 2019;19(1):417.

13. Mohammed S, Tilahun M, Tamiru D. Morbidity and associated factors of diarrheal diseases among

Loading [MathJax]/jax/output/CommonHTML/jax.js t, Southern Ethiopia, 2012. Sci J Public Health. 2013;1(2):102- 
6.

14. Amamo DD, Selgedo MB, Dukale YH. Prevalence of acute diarrhea and associated precipitating factors among under-five children in West Guji Zone, Oromia Region, Ethiopia, 2018: Community based cross sectional study. Journal of Infectious Diseases and Immunity. 2020;12(1):1-12.

15. Hashi A, Kumie A, Gasana J. Prevalence of diarrhoea and associated factors among under-five children in Jigjiga District, Somali Region, Eastern Ethiopia. Open Journal of Preventive Medicine. 2016;6(10):233-46.

16. Onyango D, Angienda P. Epidemiology of waterborne diarrhoeal diseases among children aged 6-36 months old in Busia-Western Kenya. Int J Biol Life Sci. 2010;6(2):984-91.

17. Woldu W, Bitew BD, Gizaw Z. Socioeconomic factors associated with diarrheal diseases among under-five children of the nomadic population in northeast Ethiopia. Tropical medicine and health. 2016;44(1):40.

18. Edwin P, Azage M. Geographical Variations and Factors Associated with Childhood Diarrhea in Tanzania: A National Population Based Survey 2015-16. Ethiopian Journal of Health Sciences. 2019;29(4).

19. Victor R, Baines SK, Agho KE, Dibley MJ. Determinants of breastfeeding indicators among children less than 24 months of age in Tanzania: a secondary analysis of the 2010 Tanzania Demographic and Health Survey. BMJ open. 2013;3(1).

20. Wilunda C, Panza A. Factors associated with diarrhea among children less than 5 years old in Thailand: a secondary analysis of Thailand multiple indicator cluster survey 2006 . Journal of Health Research. 2009;23(Suppl.):17-22.

21. Woldemicael G. Diarrhoeal morbidity among young children in Eritrea: environmental and socioeconomic determinants. Journal of health, population and nutrition. 2001:83-90.

22. Boadi KO, Kuitunen M. Childhood diarrheal morbidity in the Accra Metropolitan Area, Ghana: socioeconomic, environmental and behavioral risk determinants. Journal of Health \& Population in Developing Countries. 2005;7(1):15-22.

23. Dewey KG, Adu-Afarwuah S. Systematic review of the efficacy and effectiveness of complementary feeding interventions in developing countries. Maternal \& child nutrition. 2008;4:24-85.

24. Mock NB, Sellers TA, Abdoh AA, Franklin RR. Socioeconomic, environmental, demographic and behavioral factors associated with occurrence of diarrhea in young children in the Republic of Congo. Social science \& medicine. 1993;36(6):807-16.

25. Getaneh T, Assefa A, Tadesse Z. Diarrhoea morbidity in an urban area of southwest Ethiopia. East African medical journal. 1997;74(8):491-4.

26. Rohmah H, Hafsah T, Rakhmilla LE. Role of Exclusive Breastfeeding in Preventing Diarrhea. Althea Medical Journal. 2015;2(1):78-81.

27. Arifeen S, Black RE, Antelman G, Baqui A, Caulfield L, Becker S. Exclusive breastfeeding reduces acute respiratory infection and diarrhea deaths among infants in Dhaka slums. Pediatrics. 
28. Lamberti LM, Walker CLF, Noiman A, Victora C, Black RE. Breastfeeding and the risk for diarrhea morbidity and mortality. BMC public health. 2011;11(3):1-12.

29. Gedefaw M, Berhe R. Determinates of childhood pneumonia and diarrhea with special emphasis to exclusive breastfeeding in north Achefer district, northwest Ethiopia: a case control study. Open Journal of Epidemiology. 2015;5(02):107.

30. Hurley WL, Theil PK. Perspectives on immunoglobulins in colostrum and milk. Nutrients. 2011;3(4):442-74.

31. Xu R-J. Development of the newborn GI tract and its relation to colostrum/milk intake: a review. Reproduction, Fertility and Development. 1996;8(1):35-48.

32. Stelwagen K, Carpenter E, Haigh B, Hodgkinson A, Wheeler T. Immune components of bovine colostrum and milk. Journal of animal science. 2009;87(suppl_13):3-9.

33. França EL, Bitencourt RV, Fujimori M, de Morais TC, Calderon IdMP, Honorio-França AC. Human colostral phagocytes eliminate enterotoxigenic Escherichia coli opsonized by colostrum supernatant. Journal of Microbiology, Immunology and Infection. 2011;44(1):1-7.

34. Tawfeek HI, Najim NH, Al-Mashikhi S. Efficacy of an infant formula containing anti-Escherichia coli colostral antibodies from hyperimmunized cows in preventing diarrhea in infants and children: a field trial. International journal of infectious diseases. 2003;7(2):120-8.

35. Godana W, Mengiste B. Environmental factors associated with acute diarrhea among children under five years of age in derashe district, Southern Ethiopia. Sci J Public Health. 2013;1(3):119-24.

36. Anteneh A, Kumie A. Assessment of the impact of latrine utilization on diarrhoeal diseases in the rural community of Hulet Ejju Enessie Woreda, East Gojjam Zone, Amhara Region. Ethiopian Journal of Health Development. 2010;24(2).

\section{Figures}




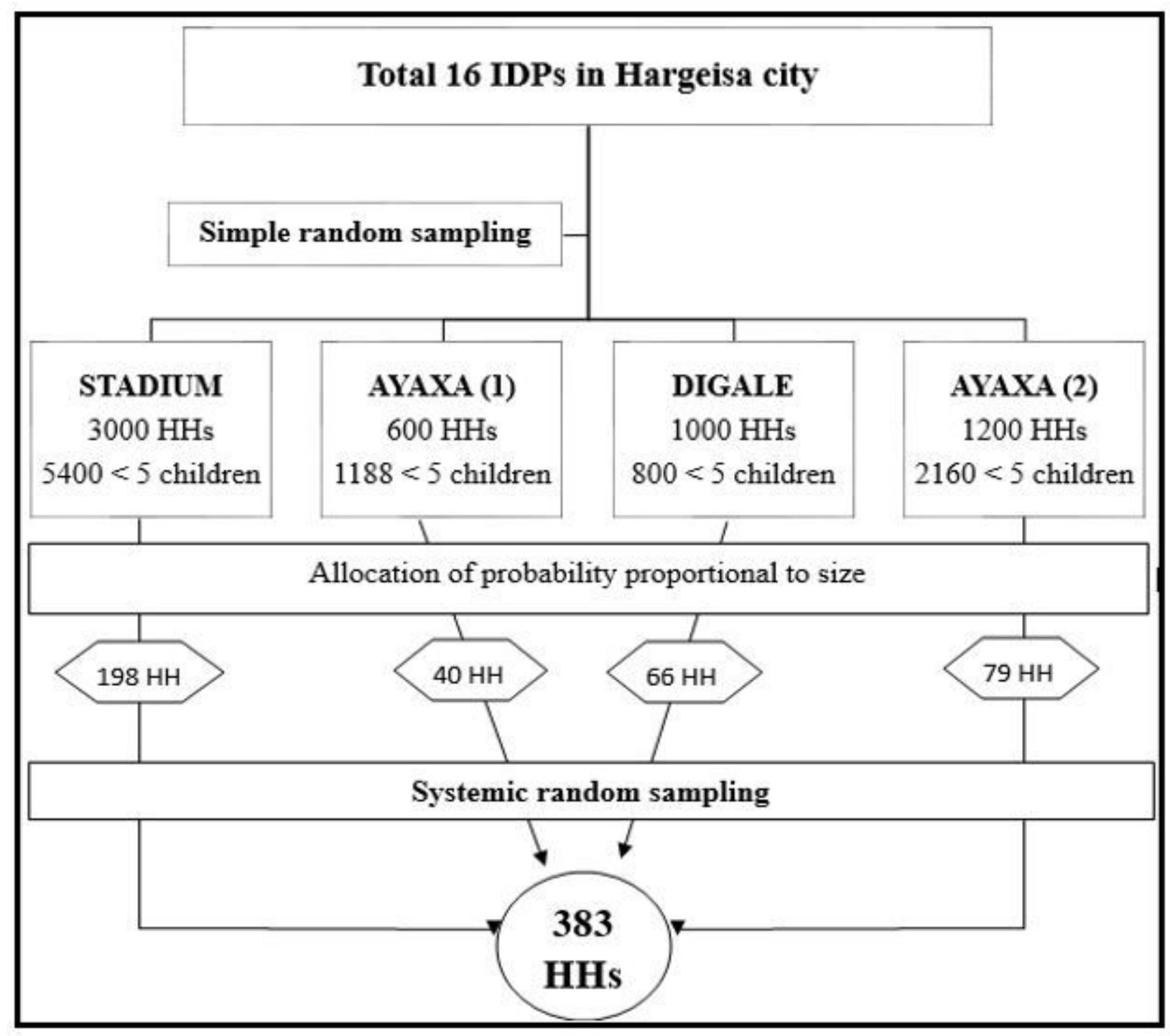

Figure 1

Sampling frame of the study participants

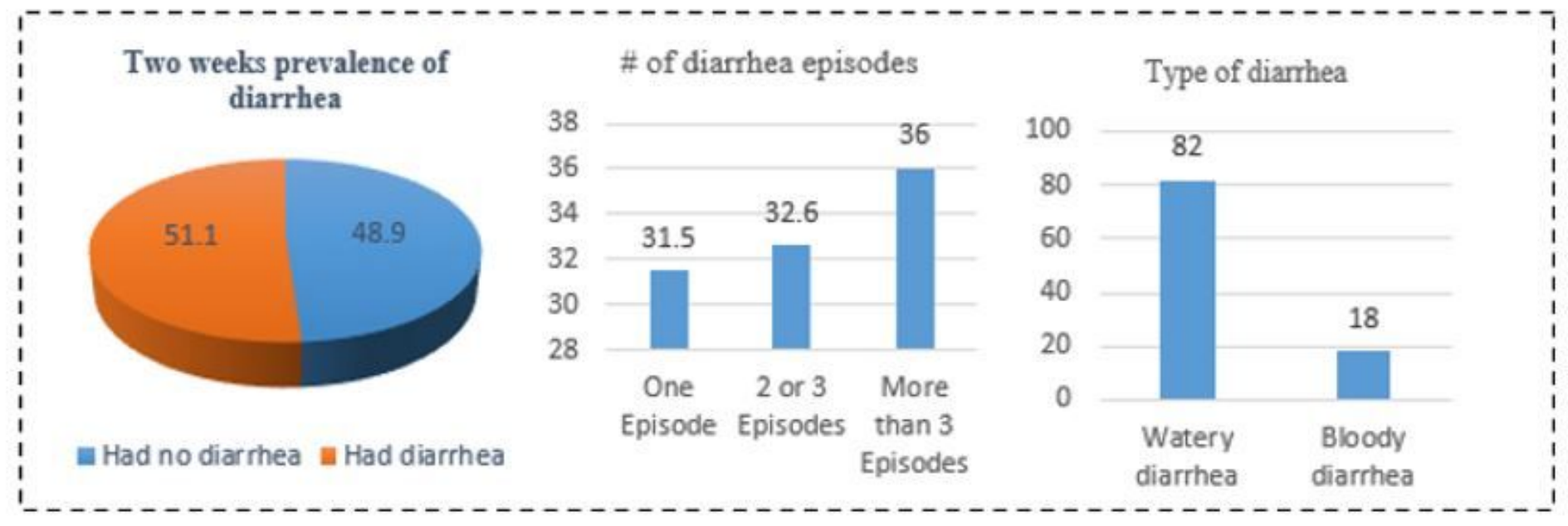


Status of diarrhea among under five children living in Hargeisa IDPs Somaliland 2020

\section{Supplementary Files}

This is a list of supplementary files associated with this preprint. Click to download.

- QuestionnaireforAcuteDiarrhea.docx

- QuestionnaireforAcuteDiarrhea.docx 